\title{
CREDIT COOPERATIVES AND THE SOCIO-ECONOMIC DEVELOPMENT OF THE COMMUNITY .
}

\author{
KAREN LUZ Y. TEVES \\ Instructor, Negros State College of Agriculture \\ Kabankalan City, Negros Occidental
}

and

ANTONIA CECILIA Y. SANDOVAL

Professor, College of Education, Leyte State University

Visca, Baybay, Leyte

\section{ABSTRACT}

Credit cooperatives have greatly contributed to the socio-economic development of the community as shown by the different incomegenerating projects implemented by members. They also had large influence on the socio-economic face-lifting of the community through the active participation of members in civic work and in the implementation of livelihood projects catering to the needs of the whole community.

KEY WORDS: Credit cooperatives. Income-generating projects. Community. 


\section{INTRODUCTION}

The concrete contribution of credit cooperatives to the socio-economic development of the community cannot be measured in terms of financial benefits alone but also in terms of intangible things like the satisfaction of needs of members, positive behavioral changes, solidarity and cooperation of members and improvement of the livelihood condition (Legaspi, 1990). On the other hand, the influence of credit cooperatives on the development of a community can be determined in terms of the livelihood projects they have implemented and projects/civic works they have supported in the community (Colis, 1989). It should be noted that credit cooperative is both an economic tool and a social movement which is composed of persons having a common interest to generate income from among themselves and in the process, develop responsibility.

The study was conducted to determine the role of credit cooperatives on the socio-economic development of the community.

\section{Conceptual Framework}

The influence of credit cooperatives on the members in terms of need satisfactiỏn, behavioral change, group solidarity and cooperation, and on socio-economic livelihood improvement varies in many ways. It is, however, believed that credit cooperatives have influenced the socioeconomic upliftment of the members and their length of membership in the organization (Figure 1). 


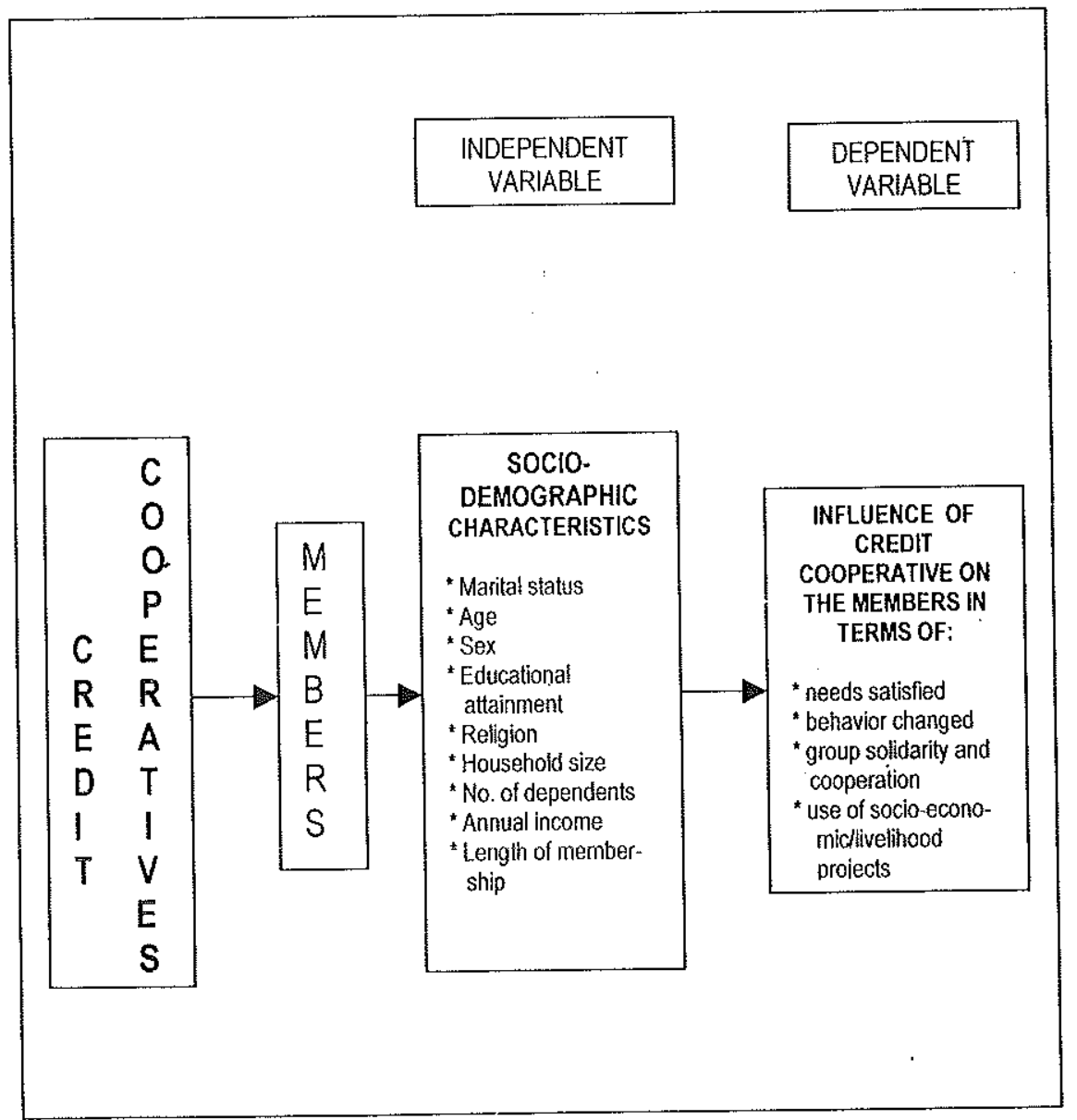

Figure 1. Schematic diagram showing the relationship among variables. 


\section{METHODOLOGY}

\section{Selection of Study Samples}

Samples were randomly selected from among members of organizations operating solely as credit cooperatives in Baybay, Leyte namely: a) Baybay Primary Credit Cooperative, b) Baybay South Central Credit Cooperative, c) Baybay North District Primary Credit Cooperative, d) Western Leyte Provincial Hospital Credit Cooperative, and e) KAMBAWAD (Kapunungan ng Mamamayan ng Baybay Water District) Primary Credit Cooperative. Respondents were chosen following the formula for determining the sample size from the total number of members per credit cooperative (Ferguson, 1989) as follows:

where:

$$
n=N / 1+N(e)^{2}
$$

$$
\begin{array}{ll}
\mathrm{n} & =\text { total sample size } \\
\mathrm{N} & =\text { population } \\
(\mathrm{e})^{2} & =\text { alpha desired (error) } \\
1 & =\text { constant }
\end{array}
$$

Samples were chosen at random. The final sample size is presented in Table 1.

Table 1. Distribution of respondents according to their credit cooperative affiliation.

CREDIT COOPERATIVE Final Sample Percent

Baybay Primary Credit Cooperative Baybay South Central Credit Cooperative

\begin{tabular}{cc} 
size & $(\%)$ \\
\hline 14 & 17.10 \\
11 & 13.41 \\
17 & 20.73 \\
29 & 35.36 \\
11 & 13.41 \\
\hline 82 & 100.00 \\
\hline
\end{tabular}

Baybay North District Primary Credit Cooperative 17

Western Leyte Provincial Hospital Credit Cooperative 29 KAMBAWAD Primary Credit Cooperative 


\section{Data Collection}

An interview schedule was used to gather information on the sociodemographic characteristics to include the impact of credit cooperative on its members in terms of needs satisfied, behavior changed, group solidarity and cooperation, the use of socio-economic projects, and the member's loan repayment performance.

Personal interviews with the top management officers (president and treasurer) of each credit cooperative were conducted to gather information on the livelihood projects and civic work/activities each credit cooperative had implemented and supported in the community. Information on the profile of loan repayment performance of credit cooperative members was also obtained.

\section{Statistical Analysis}

Statistical analyses were carried out with the aid of SPSS version (1990). Descriptive analysis using totals, means, ranges, percentages and standard deviations was made. Frequency counts were used for categorical data such as gender, religion, marital status, members' responses to the influence of credit cooperatives and others.

The chi-square test was used to analyze the relationship between socid-demographic characteristics of members and the influence of credit cooperatives on the socio-economic life of members using the following formula (Ferguson, 1989):

$$
\begin{aligned}
& \text { Where: } \begin{array}{ll}
X^{2} & =\sum(O-E) 2 / E \\
X^{2} & =\text { chi-square value } \\
O & =\text { observed value } \\
E & =\text { expected frequency }
\end{array}
\end{aligned}
$$




\section{RESULTS AND DISCUSSION}

\section{Credit Cooperatives and Members' Needs}

More than two-thirds (57 or $69.5 \%$ ) of the credit cooperative memberrespondents were members of the credit cooperative for 3 years and about a third $(30.5 \%)$ were members for 1 to 2 years (Table 1 ). This implies that the operation of credit cooperatives under study has just started.

Table 1. Distribution of respondents according to length of membership.

\begin{tabular}{ccc}
\hline $\begin{array}{c}\text { Length of Membership } \\
\text { (years) }\end{array}$ & $\begin{array}{c}\text { Frequency } \\
(n=82)\end{array}$ & $\begin{array}{c}\text { Percentage } \\
(\%)\end{array}$ \\
\hline & & \\
$1-2$ & 25 & 30.5 \\
3 & 57 & 69.5 \\
\hline Total & 82 & 100.0 \\
\hline
\end{tabular}

Majority of the respondents joined their credit cooperative because of the benefits they could obtain from being members (Table 2) This finding implies that members believe that credit cooperative is an organization of service. Rola (1987) also cited that credit cooperative is an organization which can effectively help the people help themselves.

Table 2. Reasons for joining the credit cooperative.

\begin{tabular}{|c|c|c|c|}
\hline Reason & Frequency* & Percentage & Rank \\
\hline Benefits of being a member & 52 & 63.4 & 1 \\
\hline Help others in need & 29 & 35.4 & 2 \\
\hline Financial needs & 23 & 28.0 & 3 \\
\hline Influenced by friends & 7 & 8.5 & 4 \\
\hline
\end{tabular}

${ }^{*}$ multiple response 
Most of the member-respondents $(47.6 \%)$ satisfied their financial needs by joining the credit cooperative; $29.3 \%$ were satisfied in terms of their need for business know-how; $26.8 \%$ of them satisfied their need for social/group acceptance, and $20.7 \%$ satisfied their need for emotional support from co-members.

Specifically, all the reasons why the member-respondents joined their credit cooperative revolved around their needs, mostly financial and personal. This observation coincides with the study of Montemayor (1983) citing a credit cooperative's success in providing credit to small farmers not just for their farm inputs but also for providential purpose. Table 3 presents the satisfaction derived by member-respondents in joining the credit cooperative.

Table 3. Satisfaction derived in joining the credit cooperative.

Variable

Financial

Business know-how

Social/group acceptance

Emotional/support from co-member

Improvement of one's personality

Prestige of the credit cooperative
Frequency

Percentage Rank

${ }^{*}$ multiple response

\section{Credit Cooperatives and Members' Behavior}

After the members have joined the credit cooperative, a great majority (93.9\%) developed the habit of saving money (Table 4). Only $12(6.1 \%)$ revealed that the credit cooperative did not influence them in saving for future use. This finding is further explained by Mabben (1973) that a member's attitude towards the need for saving money, responsible borrowing and group cooperation will be positively changed through the process of educating them in terms of the vision, mission, and entire operation of the credit cooperatives. 
Table 4. Respondents' idea of saving money.

\begin{tabular}{lcc}
\hline \hline Response & $\begin{array}{c}\text { Frequency } \\
(\mathrm{n}=82)\end{array}$ & $\begin{array}{c}\text { Percentage } \\
(\%)\end{array}$ \\
\hline Yes, I like saving money & 77 & 93.9 \\
No, I don't like to save money & 5 & 5.1 \\
\hline Total & & \\
\hline
\end{tabular}

After having joined the credit cooperative, majority $(80.5 \%)$ of the members learned to like lending others their money. Of the total number of respondents, $19.5 \%$ still did not like to lend their money to others. Money lending is one way of helping others in need.

Table 5. Respondents' idea of borrowing money.

\begin{tabular}{lcc}
\hline \hline Response & $\begin{array}{r}\text { Frequency } \\
(\mathrm{n}=82)\end{array}$ & $\begin{array}{c}\text { Percentage } \\
(\%)\end{array}$ \\
\hline & & \\
Yes, I like borrowing money & 70 & 85.4 \\
No, I do not like borrowing money & 12 & 14.6 \\
\hline Total & 82 & 100.0 \\
\hline \hline
\end{tabular}

\section{Credit Cooperatives and Community.}

Only one credit cooperative ventured into a grocery store catering to the needs of the members including the people in the community (Table 5). Three credit cooperatives claimed that they only extended support to the community programs and events like fiesta, educational activities, civic/charitable work of parish church, while one cooperatives claimed to have sponsored a training program for the benefit of out-of-school youths. 
Table 5. Livelihood projects and civic work/activities supported by credit cooperatives.

\begin{tabular}{lcc}
\hline \hline Activity & Frequency $^{*}$ & $\begin{array}{c}\text { Percentage } \\
(\%)\end{array}$ \\
\hline Civic work/activities & 3 & \\
Livelihood projects & 1 & 60.0 \\
Educational-training & 1 & 20.0 \\
None & 1 & 20.0 \\
\hline \hline
\end{tabular}

${ }^{\star}$ multiple response

\section{CONCLUSION AND RECOMMENDATION}

Educated members of credit cooperatives can work well with the group because they can adjust more easily to the different personalities of co-workers. The influence of credit cooperatives on the socio-economic upliftmeni of the community is also evident because members had actively participated in the implementation of civic activities amd livelihood projects for the improvement of the community.

It is suggested that the influence of credit cooperatives on the socioeconomic life of members should be recognized as a crucial contributing factor to the success of the organization. Furthermore, it is recommended that credit cooperatives should implement more livelihood projects to make a visible contribution to the development of the whole community. 


\section{LITERATURE CITED}

COLIS, J.C. 1989. Borrowing Behavior and Repayment Performance of farmer-Members in the Hilongos Credit Cooperative, Inc (HCCl). Unpublished Undergraduate Thesis. Visayas State College of Agriculture, Baybay, Leyte

LEGASPI, P. 1990. The Genesis, Viability and Effectiveness of Community Organization: The Case of Pangasinan Credit Cooperatives. Phil. Journ. Pub.Adm. 34(3) 252-272.

FERGUSON, G.A. 1989. Statistical Analysis in Psychology and Education. $6^{\text {th }}$ ed. McGraw Hill Book Company. New York.

MABBUN, P.N. and M.M. LEUTERIO. 1973. Cooperatives: Principles, Practices, Progress and Problems. Alemar-Phoenix Publishing, Quezon City. pp 98-109.

MONTEMAYOR, R. 1983. A Case Study on a Framer-Initiated Financing Scheme: The Davao FFCl Cash Bond program. In: Papers and Proceeding of the $29^{\text {th }}$ Annual Convention of the PAEDA, Inc. June 1987.

ROLA, L. 1987. Imperatives to Strengthen the Cooperation Movement in the Philippines. Journ. Agric. Econ. Dev. 16:40-48. 


\section{ABOUT THE AUTHOR}

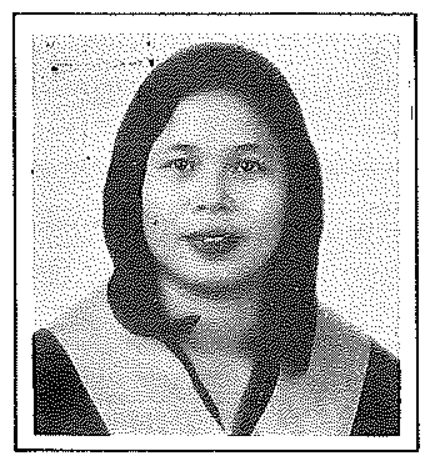

The senior author finished her BS in Food Technology degree at the then Visayas State College of Agriculture (ViSCA), now the Leyte State University (LSU), in 1991. However, her work experiences at the DSWD Regional Office No. VII, Central Mindanao University (CMU) and CMU-DOST joint outreach program had made her decide to shift career and focus on

extension work. She then took up MS in Agricultural Extension at the Leyte State University.

She is now connected with the Negros State College of Agriculture (NSCA) in Kabankalan City, Negros Occidental as Instructor I teaching Agricultural Extension courses and is currently designated as Head of the Agricultural Extension Section of NSCA . 